\title{
Magnetic Nanoparticles with Surface Nanopockets for Highly Selective Antibody Isolation
}

D. Randil K. Weerasuriya, ${ }^{\dagger}$ Snehasis Bhakta, ${ }^{\dagger},{ }^{\imath}$ Keshani Hiniduma, ${ }^{\dagger}$ Chandra K. Dixit, ${ }^{\dagger}$ Min Shen, ${ }^{\dagger}$ Zachary Tobin, ${ }^{\dagger}$ Junkai He, ${ }^{\dagger}$ Steven L. Suib ${ }^{*} \dagger, \S$ and James F. Rusling ${ }^{*}, \dagger, \S, \perp, \|$

${ }^{\dagger}$ Department of Chemistry, University of Connecticut, Storrs, Connecticut 06269-3060

${ }^{\S}$ Institute of Materials Science, University of Connecticut, Storrs, Connecticut 06269-3136

${ }^{\perp}$ Department of Surgery, Uconn Health Center, Farmington, Connecticut 06030

$\|_{\text {School of Chemistry, National University of Ireland at Galway, Galway, Ireland }}$

${ }^{2}$ Cooch Nehar College, Cooch Behar Panchanan Barma University, WB, India, 736101

Email: james.rusling@uconn.edu steven.suib@uconn.edu

\section{Supporting Information}

Table of Contents

Experimental Section .................................................................................................................2

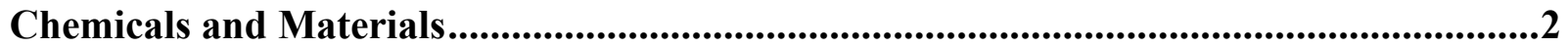

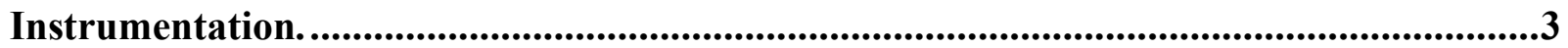

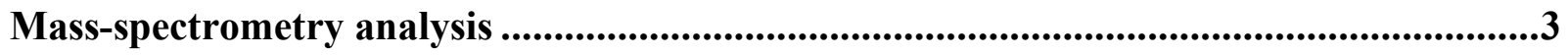

Supplementary Data .......................................................................................................6

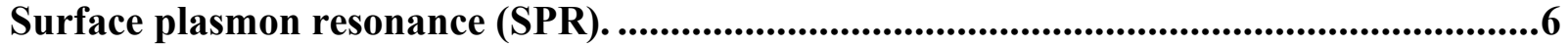

Figure S1. SPR responses at flow $35 \mu \mathrm{L} / \mathrm{min}$ for association $(0-200 \mathrm{sec})$ and dissociation $(200-400 \mathrm{sec})$ of $(\mathrm{A}) \mathrm{NP}_{\mathrm{A}}$, (B) $\mathrm{MB}_{\mathrm{A}}$ on an $\mathrm{IgG}_{2 \mathrm{a}}$-derivatized SPR chip. Chips were

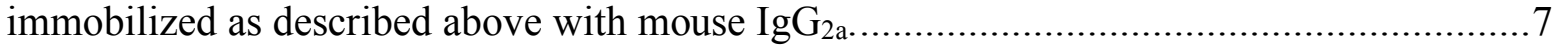

Figure S2. Initial rates of SPR response vs. concentrations of (a) $\mathrm{NP}_{\mathrm{A}}$, and (b) $\mathrm{MB}_{\mathrm{A}}$. Slopes represent the apparent association rate constants. .............................................. 7

Mass-spectrometry. ..............................................................................................

Table S1. (U)HPLC gradient used for peptide separation......................................... 8

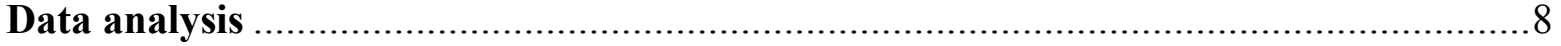

Figure S3. Representative extracted ion chromatogram of 10 MRM transitions (peaks) of tryptic peptides from 10 different proteins in untreated human serum sample after horse myoglobin (MB) spiking and trypsin digestion...................................................

Table S2. Selected MRM peptides for protein quantitation. ..................................... 10 
Dynamic Light Scattering .....................................................................................................12

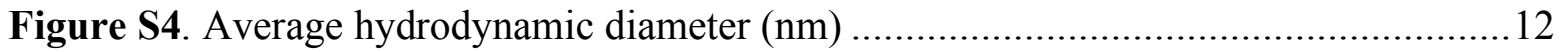

Figure S5. Elemental mapping using energy-disperse X-ray spectroscopy (EDX) analysis of NPA. 13

Fourier transform-infrared spectroscopy (FT-IR).................................................13

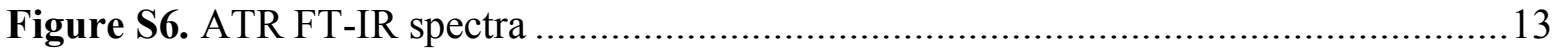

XPS Analysis of the NPs.................................................................................14

Figure S7. XPS spectra for antibody-binding NPA................................................ 15

Specificity test using an electrochemiluminescence (ECL) protein assay........................15

Figure S8. ECL assay for PSA in spiked PSA-spiked human serum (HS) treated with NPA

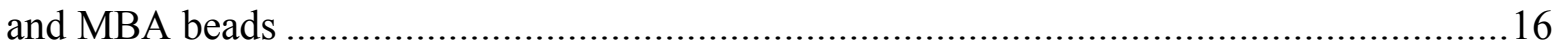

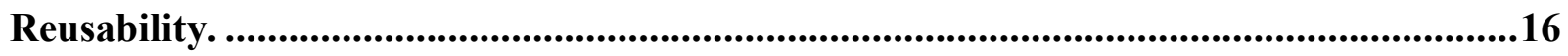

Table S3. Binding capacity $(\mu \mathrm{g} / \mathrm{mg}$ ) values for NPA and MBA tested for reusability ........ 16

Gel electrophoresis .................................................................................................17

Figure S9. Isolation of antibodies from human serum analysed by SDS-PAGE electrophoresis. .......................................................................................... 18

Statistics of adsorption isotherm .......................................................................19

Table S4. Reduced Chi-Squared and Reduced Sum of Square values generated for $\mathrm{NP}_{\mathrm{A}}$ and

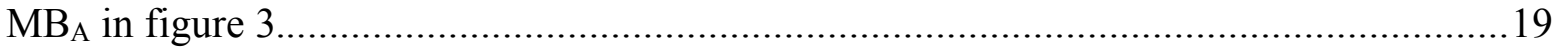

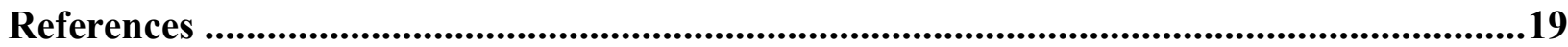

\section{Experimental Section}

Chemicals and Materials Tetraethylorthosilicate (TEOS, $\geq 99 \%$ ), (3-aminopropyl)triethoxysilane (APTES, $\geq 98 \%$ ), glutaraldehyde (Grade I, 25\% in water), human serum albumin (HSA, lyophilized powder), anti-human IgG (Fab specific)-FITC antibody produced in goat, sodium hydroxide, ethanol (200 proof), human $\operatorname{IgG}_{1}$, human $\mathrm{IgG}_{2}$, human $\operatorname{IgA}$, hydrochloric acid (ACS reagent 37\%), triton X-100, TWEEN 20, sodium periodate, sodium sulfite, sodium bicarbonate, sodium phosphate dibasic and sodium phosphate monobasic, BCA assay (Bicinchoninic acid), propyl-N-ethylcarbodiimide (EDC), N-Hydroxysulfosuccinimide (NHSS), glycine, HPLC grade water, acetonitrile (ACN), formic acid (FA), acetone, and other chemicals 
were from Sigma-Aldrich unless otherwise noted. Hydroxymethyltriethoxysilane (HMTEOS), npropyltriethoxysilane (PTES), benzyltriethoxysilane (BTES) were from Gelest, Inc. Silica modified $\mathrm{SiO}_{2} @ \mathrm{Fe}_{2} \mathrm{O}_{3}$ paramagnetic nanoparticles was from Chemicell. The surface plasmon resonance (SPR) chip functionalized with polyethylene glycol/carboxylate was from Reichert Technologies Life Sciences (part number 13206061). Staphylococcal Protein A recombinant was purchased from Prospec. All solutions were prepared using $18 \mathrm{M} \Omega \mathrm{cm}$ water purified by passing house-distilled water through a Hydro Service and Supplies purification system. Solutions were passed through $0.45 \mu \mathrm{m}$ filters (Fisher) before use. Buffer for most experiments was $10 \mathrm{mM}$ phosphate, $\mathrm{pH} 7.3$.

Instrumentation. Scanning Electron Microscopy (SEM) was performed with a Teneo LVSEM from FEI and Transmission (Scanning) Electron Microscopy (TEM/STEM) was done with a Talos F200X from FEI. Dynamic Light Scattering (DLS) was done with an ALV/CGS-3. Zeta potential measurements were done using ZetaPlus (Brookhaven Instruments Corp.) Zeta potential analyzer. Absorption spectra were obtained on a HP8453 UV-visible spectrophotometer (Agilent Technologies, Santa Clara, CA). The surface plasmon resonance (SPR) experiments were done with a Reichert Analytical Instruments SPR700DC dual channel flow spectrometer on a gold SPR chips prefunctionalized with a mixed monolayer $(10 \% \mathrm{COOH}-)_{6}$-alkanethiol and $90 \% \mathrm{OH}-$ $(\mathrm{PEG})_{3}$-alkanethiol) at $25^{\circ} \mathrm{C}$. Fluorescence intensity was measured using FlexStation 3 microplate reader from Molecular devices.

Mass-spectrometry analysis. Mass-spectrometry was performed to analyze the number of antibodies isolated after treating serum samples with both protein A nanoparticles and the commercial magnetic beads. All samples started with $20 \mu \mathrm{L}$ untreated human serum samples, went through different isolation procedures. A $25 \mu \mathrm{L}$ of the commercial protein A magnetic beads 
$\left(\mathrm{MB}_{\mathrm{A}}\right)$ was taken in an Eppendorf tube and washed twice with $\mathrm{PB}(\mathrm{pH} 7.8)$ and finally $20 \mu \mathrm{L}$ human serum was added on the magnetic beads pellet. Then, $480 \mu \mathrm{L} \mathrm{PB} \mathrm{(pH} \mathrm{7.8)} \mathrm{was} \mathrm{added} \mathrm{and}$ incubated for 30 minutes with agitation at room temperature. Thereafter, magnetic field was applied and supernatant was collected for mass-spectrometry analysis. The pellet was washed for 3 times with $\mathrm{PB}(\mathrm{pH} 7.8)$ and then the antibodies bound onto the beads was eluted using $0.2 \mathrm{M}$ glycine ( $\mathrm{pH}$ 2.5). In short, $50 \mu \mathrm{L}$ of $0.2 \mathrm{M}$ glycine $(\mathrm{pH} 2.5)$ was added to the bead pellet, vortexed and incubated for 5 mins at room temperature with agitation. Then, using a magnet the beads was separated and supernatant was collected in an Eppendorf tube. The elution step was repeated one more time to isolate all the antibodies. All the eluted sample was collected and mass-spectrometry was performed to analyze the sample. The low acidic $\mathrm{pH}$ due to glycine was neutralized by adding $20 \mu \mathrm{L}$ TRIS-HCl (pH 9.0) and the pellet was washed at least 5 times with $\mathrm{PB}(\mathrm{pH}$ 7.3) for reuse. While reusing the material, exactly same protocol was followed for $20 \mu \mathrm{L}$ human serum.

Similarly, for our synthesized protein A like magnetic nanopockets $\left(\mathrm{NP}_{\mathrm{A}}\right), 2 \mathrm{mg}$ nanoparticles suspension was taken in an Eppendorf, washed with $\mathrm{PB}(\mathrm{pH} 7.8)$ twice and then 20 $\mu \mathrm{L}$ human serum was added. As mentioned above, we followed exactly same protocol for our $\mathrm{NP}_{\mathrm{A}}$ as well and all the samples were collected as mentioned above for further analysis by using massspectrometry. We also performed gel-electrophoresis on both the antibody isolated supernatant samples and eluted samples.

After spiking $1 \mathrm{mg} / \mathrm{mL}$ horse heart myoglobin as internal standard to each sample, urea was added to give a solution of $22 \mu \mathrm{g}$ total protein with $6 \mathrm{M}$ urea. Protein reduction was carried out by adding $2 \mu \mathrm{l}$ of $200 \mathrm{mM}$ DTT (dithiothreitol) to the sample solution, followed by $30 \mathrm{~min}$ incubation at room temperature. Then the samples bearing reduced free thiol groups were alkylated by incubating $2 \mu \mathrm{l}$ of $1 \mathrm{M}$ iodoacetamide (IAA) in dark for another $30 \mathrm{~min}$ at room temperature. 
Excess IAA was further neutralized by $10 \mu \mathrm{l}$ of DTT. The resulting samples were chilled by adding cold $\left(-20^{\circ} \mathrm{C}\right)$ acetone; another 5 volumes of cold acetone were then added sequentially, followed by overnight incubation at $-20{ }^{\circ} \mathrm{C}$. After centrifugation at 13,000 under $4{ }^{\circ} \mathrm{C}$ for $30 \mathrm{~min}$, the supernatants were discarded and the pallets were washed with acetone:water (6:1) three times. The pellets were then air-dried and digested by sequencing grade modified trypsin (Promega Corporation) in a trypsin/protein (w/w) ratio of 1:100 for 18 hours. The digestion was stopped by adding FA (formic acid) to approximately $\mathrm{pH} 3$, and then the tryptic peptides were filtered through a $3 \mathrm{kDa}$ cutoff filtration plate (Pall Corporation) and subjected to LC-MS/MS analysis. All samples were pipetted in autosampler vials containing glass inserts (low volume insert, $150 \mu \mathrm{L}$, with plastic spring, Waters).

For the analysis of the digested samples, a Thermo Scientific Dionex Ultimate 3000 UHPLC interfaced to a Thermo Scientific TSQ Quantiva triple quadrupole mass spectrometer was used. Peptide separation was conducted using a Jupiter C18 column $(150 \times 0.50 \mathrm{~mm}, 5 \mu \mathrm{m}$, Phenomenex) with mobile phase of solvent A (98.8\% water, $1.0 \% \mathrm{ACN}$ and $0.2 \% \mathrm{FA})$ and $\mathrm{B}$ $(1.0 \%$ water, $98.8 \% \mathrm{ACN}$ and $0.2 \% \mathrm{FA})$ in a 30 min gradient mode with a flow rate of $15 \mu \mathrm{L} \mathrm{min}^{-}$ ${ }^{1}$ (Table S2). Multiple reaction monitoring (MRM) was operated on the TSQ Quantiva mass spectrometer, which ran multiple $\mathrm{m} / \mathrm{z}$ transitions (precursor/product ion pairs) in a cycle time of $1.000 \mathrm{~s}$ (Table S3). Key MRM-MS instrument parameters were set as ion source type = H-ESI, Spray voltage positive ion $(V)=3900$, Sheath Gas $(A r b)=20$, Aux Gas $($ Arb $)=7$, Sweep Gas $($ Arb $)=2$, Ion Transfer Tube Temp $\left({ }^{\circ} \mathrm{C}\right)=325$, Vaporizer Temp $\left({ }^{\circ} \mathrm{C}\right)=33$, APPI lamp $=$ Not in use. 


\section{Supplementary Data}

Surface plasmon resonance (SPR). SPR was done at $25^{\circ} \mathrm{C}$ using phosphate buffer with $0.05 \%$ TWEEN-20 (pH 7.3) as flow buffer with the SPR chip attached to an injection valve with a 100 $\mu \mathrm{L}$ injection loop. In brief, protein $\operatorname{IgG}_{2 \mathrm{a}}(0.5 \mathrm{mg} / \mathrm{mL})$ was first immobilized on a carboxylate functionalized gold chip using standard EDC amide coupling chemistry. ${ }^{1}$ Carboxyl groups were activated using a 1:2 mixture of freshly prepared $4 \mathrm{mg}$ EDC (3-(N, N-dimethylamino) propyl-Nethylcarbodiimide) and $11 \mathrm{mg}$ NHSS (N-Hydroxysulfosuccinimide) by flowing for $10 \mathrm{~min}$ at 10 $\mu \mathrm{L} / \mathrm{min}$. Then, the proteins in buffer were immobilized at a flow rate of $5 \mu \mathrm{L} / \mathrm{min}$ for $1200 \mathrm{sec}$. Unreacted sites were blocked using $1 \mathrm{M}$ Glycine at $\mathrm{pH} 8.0$ buffer.

The $\mathrm{NP}_{\mathrm{A}}$ used for these experiments were prepared on smooth core-shell NPs. $\mathrm{NP}_{\mathrm{A}}$ dispersions in buffer were injected into the SPR via the sample injection loop to monitor binding to surface proteins at a $35 \mu \mathrm{L} / \mathrm{min}$ flow rate, allowing $200 \mathrm{~s}$ for association and $200 \mathrm{~s}$ for dissociation. SPR response $\mathrm{R}$ was initially analyzed by fitting eqs 1 and suing 2 to estimate the association binding constant $k_{a}$ and dissociation rate constant $k_{d}$. However, binding of $\mathrm{NP}_{\mathrm{A}}$ to proteins did not show any dissociation even after $7 \mathrm{~h}$. of dissociation time, and the data give very poor fits to this model. The rate of change in signal vs. time during association for each experiment was then plotted against $\left[\mathrm{NP}_{\mathrm{A}}\right]$ and the apparent association rate constant was estimated from the slope (eq 4). Similarly, $\mathrm{MB}_{\mathrm{A}}$ dispersions were used in SPR as described above and the association binding constant $k_{a}$ was determined for comparison.

$$
\begin{aligned}
& \mathrm{R}_{\mathrm{t}}=\mathrm{C}_{a} \mathrm{R}_{\max }\left[1-\exp \left(\left(\mathrm{C} k_{a}+k_{d}\right) \mathrm{t}\right)\right] /\left(\mathrm{C} k_{a}+k_{d}\right) \\
& \mathrm{R}_{\mathrm{t}}=\mathrm{R}_{\max } \exp \left(-k_{d} \mathrm{t}\right) \\
& \mathrm{K}_{\mathrm{D}}=k_{d} / k_{a}
\end{aligned}
$$


$\Delta \mathrm{R} / \Delta \mathrm{t}=k_{a}[\mathrm{Ab}]$

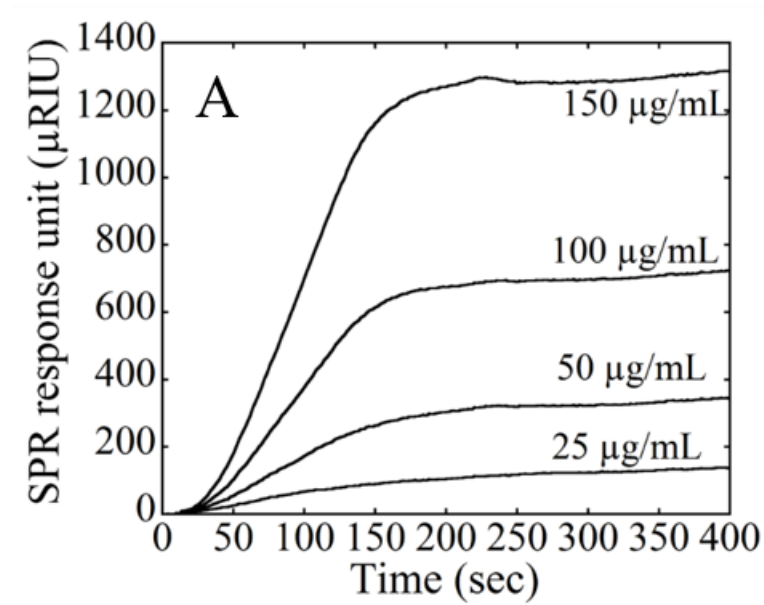

(4)

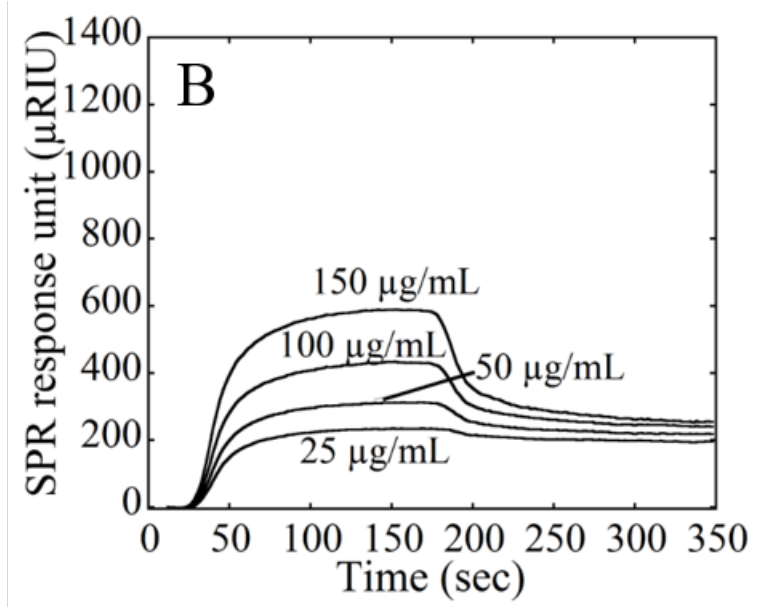

Figure S1. SPR responses at flow $35 \mu \mathrm{L} / \mathrm{min}$ for association $(0-200 \mathrm{sec})$ and dissociation (200$400 \mathrm{sec}$ ) of (A) $\mathrm{NP}_{\mathrm{A}}$, (B) $\mathrm{MB}_{\mathrm{A}}$ on an $\mathrm{IgG}_{2 \mathrm{a}}$-derivatized $\mathrm{SPR}$ chip. Chips were immobilized as described above with mouse $\operatorname{IgG}_{2 a}$.

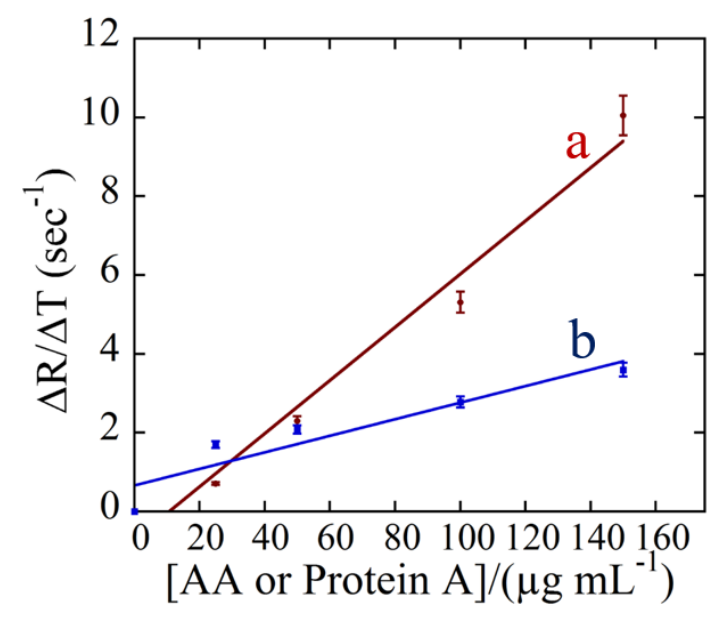

Figure S2. Initial rates of SPR response vs. concentrations of (a) $\mathrm{NP}_{\mathrm{A}}$, and (b) $\mathrm{MB}_{\mathrm{A}}$. Slopes represent the apparent association rate constants.

Figures S1A and Figure S1B show SPR responses (R) for $\operatorname{IgG}_{2 \mathrm{a}}-\mathrm{NP}_{\mathrm{A}}$ and $\operatorname{IgG}_{2 \mathrm{a}}$-proteinA binding. Non-linear regression fits to the model in eqs 2 and 3 for the SPR data gave poor fits, most likely due to co-operative surface interactions. Thus, apparent association rate constants $\left(k_{\mathrm{a}}\right.$, eq 5) were estimated from initial slopes $(\Delta \mathrm{R} / \Delta \mathrm{t})$ of plots of $\Delta \mathrm{R} / \Delta \mathrm{t}$ vs. [Protein $\mathrm{A}$ or $\mathrm{NP}_{\mathrm{A}}$ ] (Figure S2). SPR responses increased with increasing $\left[\mathrm{NP}_{\mathrm{A}}\right]$ (Figure $\mathrm{S} 1 \mathrm{~A}$ ) with $\mathrm{IgG}_{2 \mathrm{a}}$ on the SPR chips. 
The apparent $k_{\mathrm{a}}$ was largest at $0.067(\mu \mathrm{g} / \mathrm{mL})^{-1} \mathrm{sec}^{-1}$ for $\mathrm{NP}_{\text {ProteinA-IgG }}$, , while natural protein A showed smaller $k_{\mathrm{a}}\left(0.021(\mu \mathrm{g} / \mathrm{mL})^{-1} \mathrm{sec}^{-1}\right)$.

\section{Mass-spectrometry.}

Table S1. (U)HPLC gradient used for peptide separation.

\begin{tabular}{|c|c|}
\hline time, $\min$ & $\mathbf{B \%}$ \\
\hline 0 & 5 \\
\hline 3 & 5 \\
\hline 18 & 20 \\
\hline 22 & 90 \\
\hline 25 & 90 \\
\hline 26 & 5 \\
\hline 30 & 5 \\
\hline
\end{tabular}

Data analysis A freely-available, open-source application, Skyline, was used to generate the transition list for MRM-MS (Table S3). The obtained MRM data were then imported back to Skyline application for determination of peak areas from each of the monitored transitions. The $1^{\text {st }}$ ranking peak area of each peptide transition is used for protein quantitation (Table S3). 


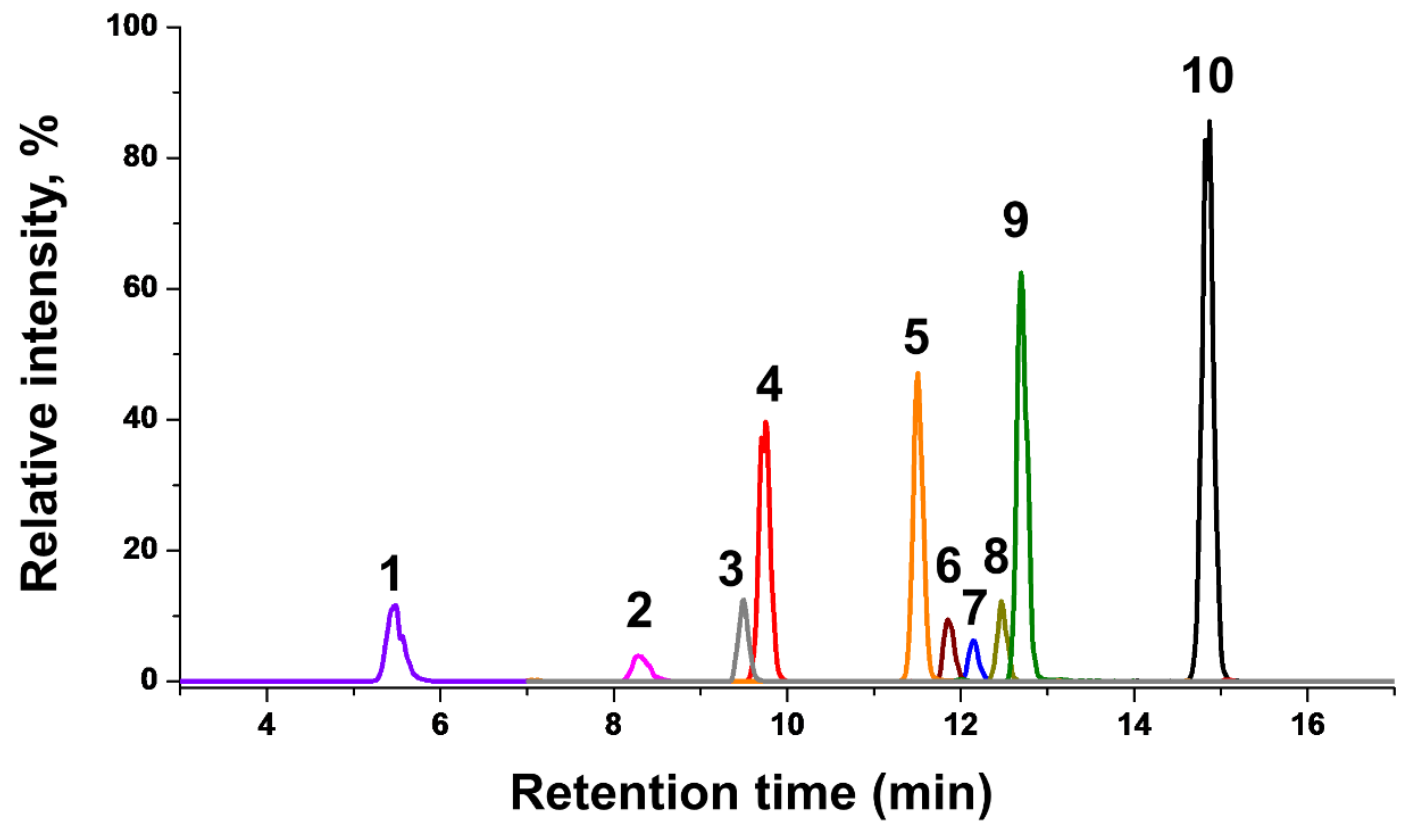

Figure S3. Representative extracted ion chromatogram of 10 MRM transitions (peaks) of tryptic peptides from 10 different proteins in untreated human serum sample after horse myoglobin (MB) spiking and trypsin digestion. 1: ATEHLSTLSEK from apolipoprotein A1 (Apo A1), 2: GLPSSIEK from human IgG4, 3: LFTGHPETLEK from myoglobin (MB), 4: GLPAPIEK from human IgG2, 5: VGYVSGWGR from haptoglobin (Hp), 6: DGFFGNPR from human IgM, 7: WYVDGVEVHNAK from human IgG3, 8: WLQGSQELPR from human IgA, 9: LVNEVTEFAK from human serum albumin (HSA), 10: GPSVFPLAPSSK from human IgG1. The intensity of peak 9 (HSA) was scaled down 10-fold. 
Table S2. Selected MRM peptides for protein quantitation. The parameters are defined as follows: protein $=$ the name of protein; selected peptide = peptide sequence for protein quantitation; collision energy $(\mathrm{CE})=$ voltage applied to the collision cell $\mathrm{q} 2$; transition mass filter $=$ product ion $\mathrm{m} / \mathrm{z}$ for protein quantitation from the precursor ion $\mathrm{m} / \mathrm{z}$; role $=$ purpose of each $\mathrm{m} / \mathrm{z}$ transition.

\begin{tabular}{|c|c|c|c|c|}
\hline Protein & Selected peptide & $\mathbf{C E}$ & Transition mass filter, $\mathrm{m} / \mathrm{z}$ & Role \\
\hline \multirow{3}{*}{$\begin{array}{c}\text { generic } \\
\text { human IgG }\end{array}$} & \multirow{3}{*}{ DTLMISR } & \multirow{3}{*}{16.5} & $418.220 \rightarrow 506.276(\mathrm{y} 4)$ & Quantitation \\
\hline & & & $418.220 \rightarrow 619.360(\mathrm{y} 5)$ & Confirmation \\
\hline & & & $418.220 \rightarrow 375.235(\mathrm{y} 3)$ & Confirmation \\
\hline \multirow{3}{*}{ human $\mathrm{IgG}_{1}$} & \multirow{3}{*}{ GPSVFPLAPSSK } & \multirow{3}{*}{22.5} & $593.826 \rightarrow 699.404(\mathrm{y} 7)$ & Quantitation \\
\hline & & & $593.826 \rightarrow 1032.572(\mathrm{y} 10)$ & Confirmation \\
\hline & & & $593.826 \rightarrow 846.472(\mathrm{y} 8)$ & Confirmation \\
\hline \multirow{3}{*}{ human $\mathrm{IgG}_{2}$} & \multirow{3}{*}{ GLPAPIEK } & \multirow{3}{*}{16.4} & $412.747 \rightarrow 654.382(\mathrm{y} 6)$ & Quantitation \\
\hline & & & $412.747 \rightarrow 557.329(\mathrm{y} 5)$ & Confirmation \\
\hline & & & $412.747 \rightarrow 486.292(\mathrm{y} 4)$ & Confirmation \\
\hline \multirow{3}{*}{ human $\mathrm{IgG}_{3}$} & \multirow{3}{*}{ WYVDGVEVHNAK } & \multirow{3}{*}{15.5} & $472.901(+3) \rightarrow 534.278$ & Quantitation \\
\hline & & & $472.901(+3) \underset{(+2)}{\rightarrow} 615.809$ & Confirmation \\
\hline & & & $472.901(+3) \rightarrow 484.743$ & Confirmation \\
\hline \multirow{3}{*}{ human $\mathrm{IgG}_{4}$} & \multirow{3}{*}{ GLPSSIEK } & \multirow{3}{*}{16.5} & $415.734 \rightarrow 660.356(\mathrm{y} 6)$ & Quantitation \\
\hline & & & $415.734 \rightarrow 563.304(\mathrm{y} 5)$ & Confirmation \\
\hline & & & $415.734 \rightarrow 476.271(\mathrm{y} 4)$ & Confirmation \\
\hline \multirow{3}{*}{ human IgA } & \multirow{3}{*}{ WLQGSQELPR } & \multirow{3}{*}{22.9} & $607.683 \rightarrow 786.410(\mathrm{y} 7)$ & Quantitation \\
\hline & & & $607.683 \rightarrow 1027.553(\mathrm{y} 9)$ & Confirmation \\
\hline & & & $607.683 \rightarrow 914.469(\mathrm{y} 8)$ & Confirmation \\
\hline \multirow{3}{*}{ human IgM } & \multirow{3}{*}{ DGFFGNPR } & \multirow{3}{*}{17.8} & $455.214 \rightarrow 590.305(\mathrm{y} 5)$ & Quantitation \\
\hline & & & $455.214 \rightarrow 794.394(\mathrm{y} 7)$ & Confirmation \\
\hline & & & $455.214 \rightarrow 737.373(\mathrm{y} 6)$ & Confirmation \\
\hline \multirow{3}{*}{$\begin{array}{l}\text { human serum } \\
\text { albumin } \\
\text { (HSA) }\end{array}$} & \multirow{3}{*}{ LVNEVTEFAK } & \multirow{3}{*}{21.9} & $575.311 \rightarrow 937.463(\mathrm{y} 8)$ & Quantitation \\
\hline & & & $575.311 \rightarrow 823.420(\mathrm{y} 7)$ & Confirmation \\
\hline & & & $575.311 \rightarrow 694.377(\mathrm{y} 6)$ & Confirmation \\
\hline \multirow{3}{*}{$\begin{array}{l}\text { haptoglobin } \beta \\
\text { chain }\end{array}$} & \multirow{3}{*}{ VGYVSGWGR } & \multirow{3}{*}{19.0} & $490.751 \rightarrow 562.273(\mathrm{y} 5)$ & Quantitation \\
\hline & & & $490.751 \rightarrow 824.405(\mathrm{y} 7)$ & Confirmation \\
\hline & & & $490.751 \rightarrow 661.342(\mathrm{y} 6)$ & Confirmation \\
\hline
\end{tabular}




\begin{tabular}{|c|c|c|c|c|}
\hline \multirow{3}{*}{$\begin{array}{l}\text { apolipoprotein } \\
\text { A1 }\end{array}$} & \multirow{3}{*}{ ATEHLSTLSEK } & \multirow{3}{*}{13.5} & $405.878 \rightarrow 577.319(\mathrm{y} 5)$ & Quantitation \\
\hline & & & $405.878 \rightarrow 777.435(\mathrm{y} 7)$ & Confirmation \\
\hline & & & $405.878 \rightarrow 476.271(\mathrm{y} 4)$ & Confirmation \\
\hline \multirow{3}{*}{$\begin{array}{l}\text { mouse } \operatorname{IgG} 2 \mathrm{a} \\
\text { light chain }\end{array}$} & \multirow{3}{*}{ TSTSPIVK } & \multirow{3}{*}{16.5} & $416.742 \rightarrow 644.398(\mathrm{y} 6)$ & Quantitation \\
\hline & & & $416.742 \rightarrow 731.430(\mathrm{y} 7)$ & Confirmation \\
\hline & & & $416.742 \rightarrow 543.350(\mathrm{y} 5)$ & Confirmation \\
\hline \multirow{3}{*}{$\begin{array}{l}\text { mouse IgG2a } \\
\text { heavy chain }\end{array}$} & \multirow{3}{*}{ DLPAPIER } & \multirow{3}{*}{17.8} & $455.753 \rightarrow 682.388(\mathrm{y} 6)$ & Quantitation \\
\hline & & & $455.753 \rightarrow 585.335(\mathrm{y} 5)$ & Confirmation \\
\hline & & & $455.753 \rightarrow 514.298(\mathrm{y} 4)$ & Confirmation \\
\hline \multirow{3}{*}{$\begin{array}{l}\text { horse hear } \\
\text { myoglobin } \\
\text { (MB) }\end{array}$} & \multirow{3}{*}{ LFTGHPETLEK } & \multirow{3}{*}{23.9} & $636.335 \rightarrow 1011.511(\mathrm{y} 9)$ & Quantitation \\
\hline & & & $636.335 \rightarrow 910.463(\mathrm{y} 8)$ & Confirmation \\
\hline & & & $636.335 \rightarrow 716.382(\mathrm{y} 6)$ & Confirmation \\
\hline
\end{tabular}




\section{Dynamic Light Scattering}
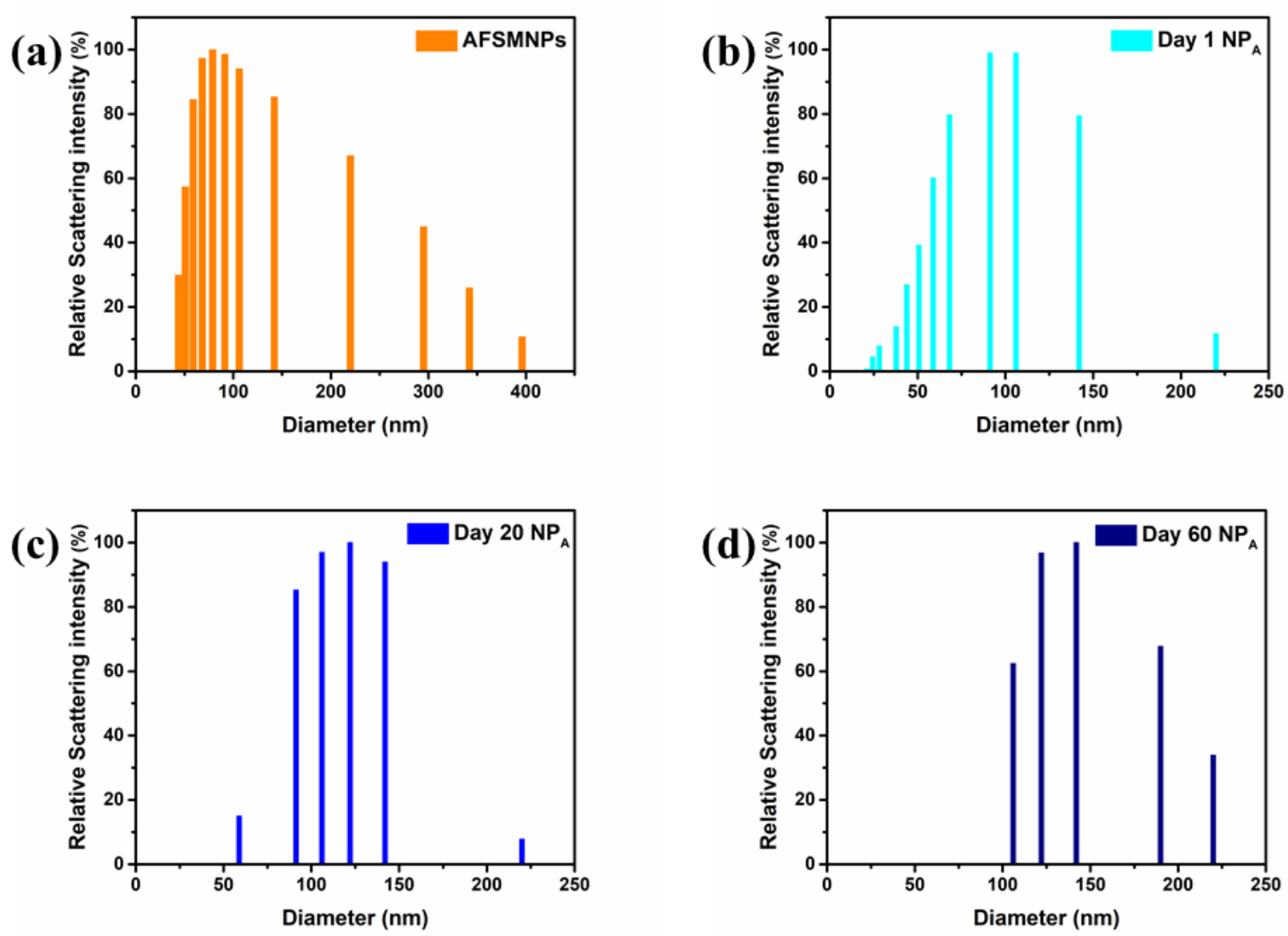

Figure S4. Average hydrodynamic diameter (nm) of (a) $100 \mathrm{~nm}$ dimeter (Ocean NanoTech) amine-functionalized silica core-shell magnetic nanoparticles (AFSMNPs; orange), and core-shell NPs (cyan) demonstrating relative stability over 60 days from initial synthesis; (b) $\mathrm{NP}_{\mathrm{A}}$ day 1 (cyan), (c) $\mathrm{NP}_{\mathrm{A}}$ day 20 (Blue) (d) $\mathrm{NP}_{\mathrm{A}}$ day 60 (dark blue), obtained using Dynamic Light Scattering (DLS) in $\mathrm{pH} 7.3 \mathrm{PBS}$.

Rough $\mathrm{NP}_{\mathrm{A}}$ used for these experiments were polymerized 1-hour.

- Average diameter of the AFSMNPs was $81 \mathrm{~nm}$, and zeta potential was $+31.5 \mathrm{mV}$

- Average diameter of $\mathrm{NP}_{\mathrm{A}}$ (Day 1; Figure 1 (b)) was $101 \mathrm{~nm}$, and zeta potential was -25.3 mV, 20 $\mathrm{nm}$ increased diameter, film thickness $10 \mathrm{~nm}$

- Average diameter of $\mathrm{NP}_{\mathrm{A}}$ (Day 20; figure 1 (c)) was $126 \mathrm{~nm}$, and zeta potential was -20.9 mV 
- IgG binding properties of $\mathrm{NP}_{\mathrm{A}}$ were not significantly different over this time period.
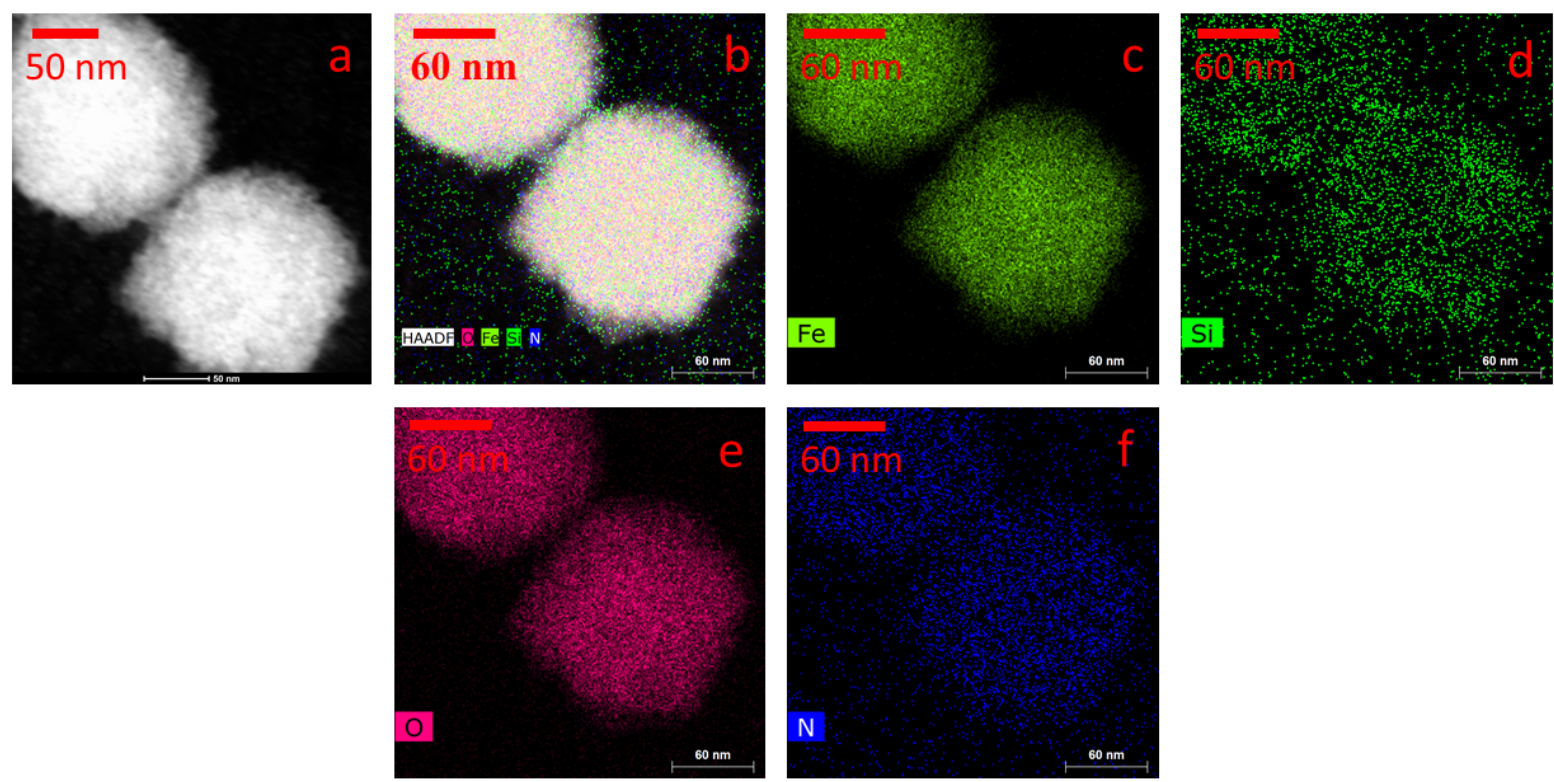

Figure S5. Elemental mapping using energy-disperse X-ray spectroscopy (EDX) analysis of NPA. (a) nanoparticle image without EDAX, (b) HAADF images overlapping all elements analyzed (c) magnetic core by $\mathrm{Fe}$ (light green), (d) Si (luminous green) by organosilanes and silica, (e) O (pink) of the organosilanes and (f) $\mathrm{N}$ from amines (blue) organosilanes, silica, and magnetic core.

\section{Fourier transform-infrared spectroscopy (FT-IR).}
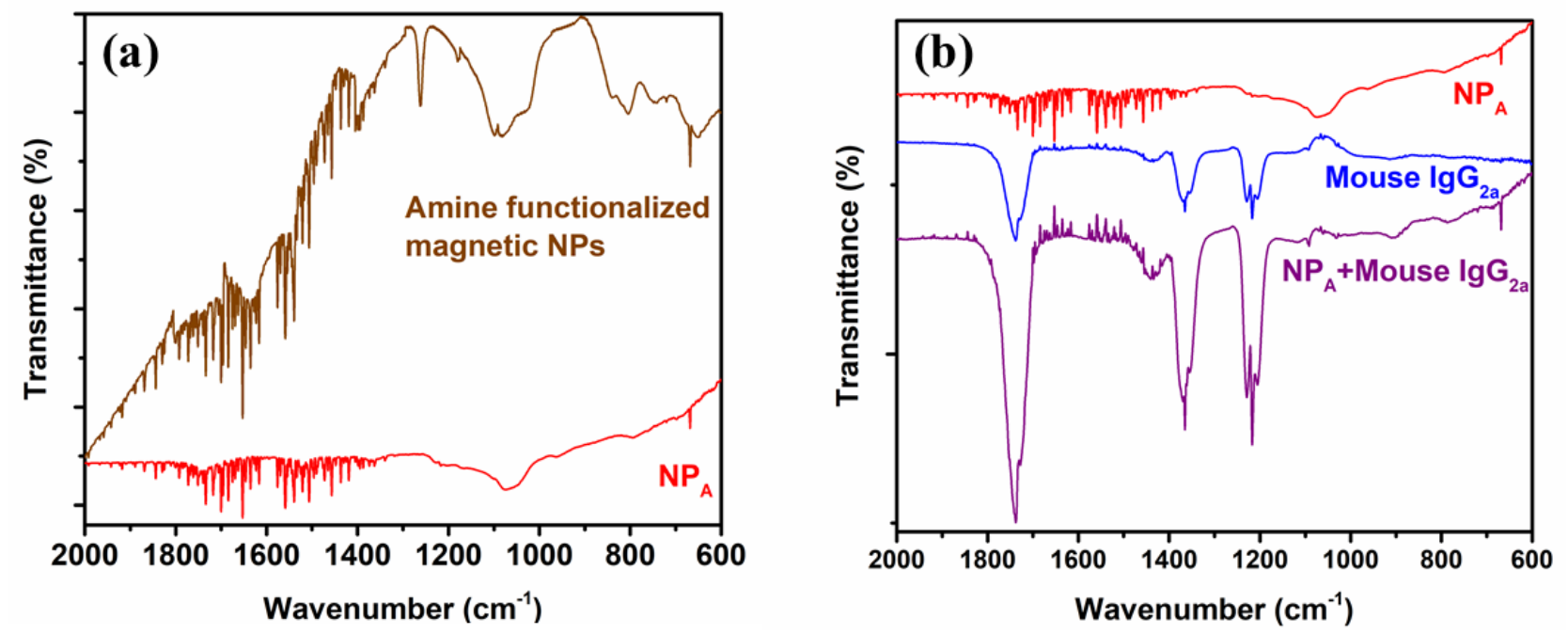

Figure S6. ATR FT-IR spectra obtained for (a) rough core-shell NPs and $\mathrm{NP}_{\mathrm{A}}$ (1-h polymerization). (b) $\mathrm{NP}_{\mathrm{A}}$, mouse $\mathrm{IgG}_{2 \mathrm{a}}$ and $\mathrm{NP}_{\mathrm{A}}$ after binding mouse $\mathrm{IgG}_{2 \mathrm{a}}$ conjugate. 
A Nicolet Magna 560 spectrometer equipped with a TGS detector was used A total of 64 scans were collected at the range of $500-4000 \mathrm{~cm}^{-1}$. Data were obtained for protein A nanoparticles, $\mathrm{IgG}_{2 \mathrm{a}}$ alone, and $\mathrm{NP}_{\mathrm{A}}$ after binding $\mathrm{IgG}_{2 \mathrm{a}}$. FT-IR spectra of $\mathrm{IgG}_{2 \mathrm{a}}$-continaing samples show a strong amide I protein band ${ }^{2}$ at $1720 \mathrm{~cm}^{-1}$ corresponding to the Amide I band of $\operatorname{IgG}_{2 \mathrm{a}}$, and additional smaller bands corresponding to the $\mathrm{IgG}$ Amide $\mathrm{III}^{3}$ at 1375 and $1200 \mathrm{~cm}^{-}$Amide I vibrational is mainly associated with the $\mathrm{C}=\mathrm{O}$ stretching vibration $(70-85 \%)$ with a small contribution of $\mathrm{N}-\mathrm{H}$ bending(10\%) and C-N stretching (10\%) vibrations, and directly related to the protein backbone conformation.

XPS Analysis of the NPs. The surfaces of the nanomaterials were analyzed by X-ray photoelectron spectroscopy (XPS), a Quantum 2000 spectrometer with scanning ESCA microprobe (Physical Electronics Industries Inc.), using Al-K radiation $(=1486.6 \mathrm{eV})$ as the radiation source. The powder samples were pressed on carbon tape mounted on adhesive copper tape stuck to a sample stage placed in the analysis chamber. The obtained XPS spectra were analyzed and fitted using CasaXPS software (version 1 It 2.3.12). The C 1s photoelectron line at $284.6 \mathrm{eV}$ was used as a reference for correction of the surface charging. A mixture of Gaussian (70\%) and Lorentzian (30\%)functions was used for the least-squares curve fitting procedure. Figure 15 confirms the presence of elements $\mathrm{Si}, \mathrm{O}, \mathrm{N}, \mathrm{C}$ on the surface probably from the amine groups, hydroxyl groups, other hydrophobic groups such as benzyl, propyl, ethyl etc. 


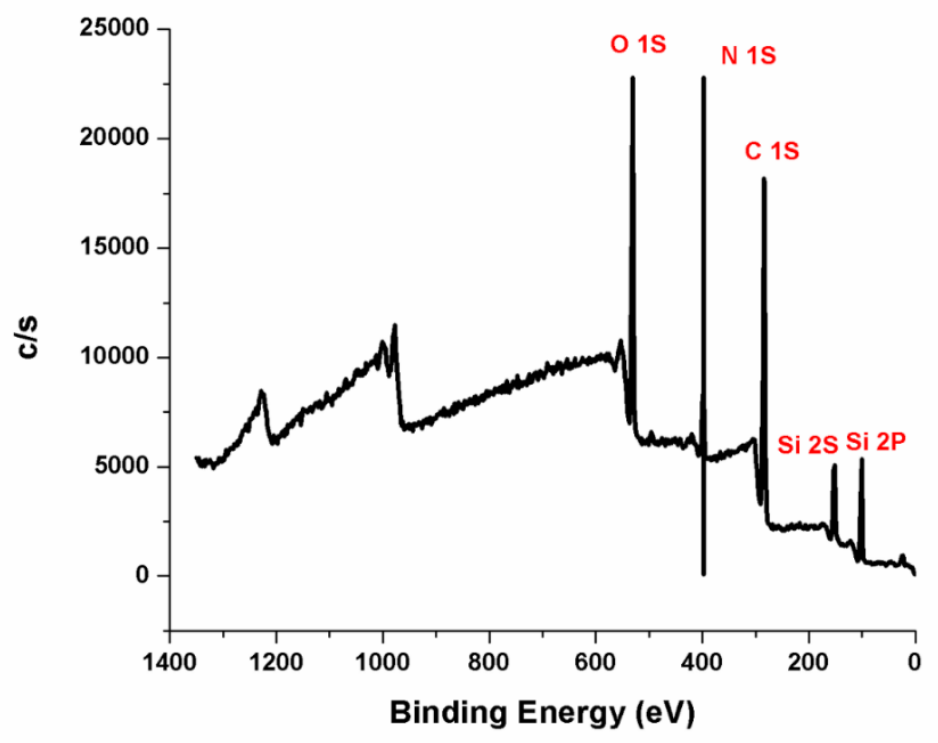

Figure S7. XPS spectra for antibody-binding NPA. The detection of $\mathrm{N}, \mathrm{Si}, \mathrm{O}, \mathrm{C}$ suggest the presence of functional groups such as amine, and hydroxyl, propyl, and benzyl groups from the precursors.

Specificity test using an electrochemiluminescence (ECL) protein assay. To demonstrate that $\mathrm{NP}_{\mathrm{A}}$ does not bind significant amounts of low abundant proteins, we spiked human serum with 10 ng $\mathrm{mL}^{-1}$ of prostate specific antigen (PSA), a low abundant serum protein $(0.5-3 \mathrm{ng} / \mathrm{mL})$. We compared relative abundance of PSA in the spiked serum samples, and the same samples treated with $\mathrm{NP}_{\mathrm{A}}$ and $\mathrm{MB}_{\mathrm{A}}$ using an in-house ECL immunoassay to detect PSA selectively. ${ }^{4}$ The relative ECL intensities were obtained with a CCD camera. The sample treated with nanoparticles have ECL signal 0.93 compared to controls whereas the commercial material treated serum samples 1.27 X times ECL signal (Figure S9) suggesting that removal of antibodies has slightly decreased the low abundant proteins in the samples. 

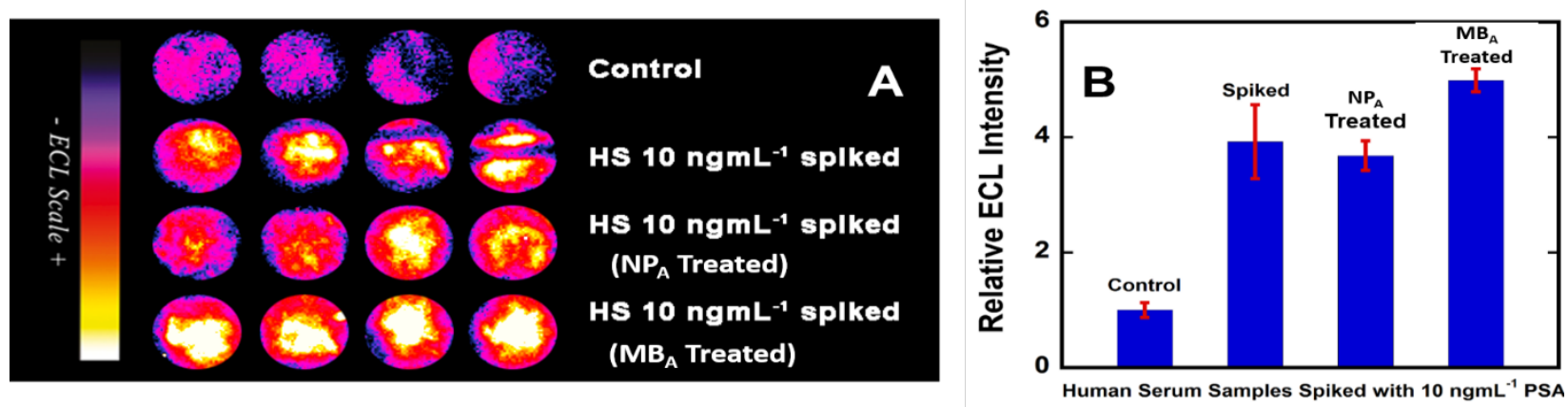

Figure S8. ECL assay for PSA in spiked PSA-spiked human serum (HS) treated with NPA and MBA beads. A) Recolorized ECL images showing ECL responses for PSA of four different

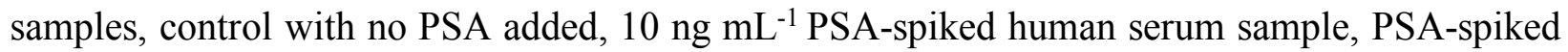
serum treated by $\mathrm{NP}_{\mathrm{A}}$ for antibody isolation, PSA-spiked human serum treated by $\mathrm{MB}_{\mathrm{A}}$ for antibody isolation; B) Bar graph showing specific ECL responses for PSA compared to control, avg. of 3 different PSA-spiked samples before and after $\mathrm{NP}_{\mathrm{A}}$ and $\mathrm{MB}_{\mathrm{A}}$ treatment. Data show not significant difference between NPA-treated and non-treated serum, suggesting no PSA removal by $\mathrm{NP}_{\mathrm{A}}$.

\section{Reusability.}

Table S3. Binding capacity ( $\mu \mathrm{g} / \mathrm{mg}$ ) values for NPA and MBA tested for reusability using methanol: acetic acid; 9:1 ( $\mathrm{pH} 5)$, and (b) NE BioLab particle regeneration protocol (0.2 M glycine- $\mathrm{HCl} \mathrm{pH} 2.5$ )

\begin{tabular}{|c|c|c|c|c|}
\hline \multirow[t]{2}{*}{$\begin{array}{c}\text { Reusability } \\
\text { cycle } \\
\text { number }\end{array}$} & \multicolumn{2}{|c|}{$\begin{array}{c}\text { Binding capacity }(\mu \mathrm{g} / \mathrm{mg}) \text { using } \\
\text { methanol: acetic acid; 9:1 (pH 5) } \\
\text { particle regeneration protocol }\end{array}$} & \multicolumn{2}{|c|}{$\begin{array}{l}\text { Binding capacity }(\mu \mathrm{g} / \mathrm{mg}) \text { using } \mathrm{NE} \\
\text { BioLab particle regeneration } \\
\text { protocol }(0.2 \mathrm{M} \text { glycine-HCl } \mathrm{pH} 2.5)\end{array}$} \\
\hline & $\mathbf{N P}_{\mathbf{A}}$ & $\mathbf{M B}_{\mathbf{A}}$ & $\mathbf{N P}_{\mathbf{A}}$ & $\mathbf{M B}_{\mathbf{A}}$ \\
\hline 1 & $78.3 \pm 4.4$ & $80.3 \pm 1.3$ & $82.5 \pm 1.5$ & $75.3 \pm 2.1$ \\
\hline 2 & $78.5 \pm 3.4$ & $74.1 \pm 0.3$ & $84.5 \pm 1.5$ & $72.4 \pm 0.6$ \\
\hline 3 & $78.3 \pm 4.8$ & $76.7 \pm 1.0$ & $70.1 \pm 2.6$ & $70.0 \pm 0.16$ \\
\hline 4 & $78.2 \pm 1.6$ & $74.5 \pm 1.3$ & $60.2 \pm 0.5$ & $70.0 \pm 0.8$ \\
\hline 5 & $78.2 \pm 3.8$ & $75.0 \pm 1.3$ & $55.8 \pm 2.3$ & $69.4 \pm 1.0$ \\
\hline 6 & $78.2 \pm 5.3$ & $69.9 \pm 3.5$ & $43.6 \pm 0.01$ & $67.2 \pm 5.7$ \\
\hline 7 & $78.1 \pm 0.4$ & $53.1 \pm 2.6$ & $31.1 \pm 2.1$ & $62.1 \pm 2.1$ \\
\hline 8 & $78.1 \pm 0.9$ & $51.0 \pm 2.5$ & $18.9 \pm 1.4$ & $60.2 \pm 2.1$ \\
\hline 9 & $77.9 \pm 2.6$ & $43.7 \pm 6.6$ & $10.0 \pm 1.0$ & $59.9 \pm 1.2$ \\
\hline 10 & $77.8 \pm 5.4$ & $40.5 \pm 2.0$ & $9.3 \pm 1.9$ & $57.9 \pm 1.9$ \\
\hline 11 & $77.6 \pm 4.0$ & $37.1 \pm 3.4$ & & $54.9 \pm 2.2$ \\
\hline 12 & $77.2 \pm 1.3$ & $24.6 \pm 1.2$ & & $51.1 \pm 2.7$ \\
\hline
\end{tabular}




\begin{tabular}{|l|l|l|l|l|}
\hline 13 & $77.1 \pm 0.4$ & & & \\
\hline 14 & $76.9 \pm 1.0$ & & & \\
\hline 15 & $76.7 \pm 1.7$ & & & \\
\hline 16 & $75.4 \pm 3.7$ & & & \\
\hline 17 & $74.6 \pm 3.7$ & & & \\
\hline 18 & $73.7 \pm 2.7$ & & & \\
\hline 19 & $71.5 \pm 4.4$ & & & \\
\hline 20 & $70.2 \pm 0.6$ & & & \\
\hline
\end{tabular}

Gel electrophoresis. Sodium dodecyl sulfate (SDS) PAGE was run to study the depleted samples. SDS-PAGE was performed in a Bio-Rad Mini-Protean electrophoresis apparatus using standard protocol. In all experiments, $10 \%$ polyacrylamide gel was used as separating gel with a $5 \%$ stacking gel. The samples were mixed with loading buffer (Tris buffer $\mathrm{pH} 6.8$ containing $2 \% \mathrm{w} / \mathrm{v}$ SDS, $10 \% \mathrm{v} / \mathrm{v} \beta$-mercaptoethanol) in 3:1 ratio and kept in boiling water for 5 minutes. Samples were loaded such that each well contained about $5 \mu \mathrm{g}$ of proteins. Then the gel was run for $1 \mathrm{~h}$ at $200 \mathrm{~V}$ for effective separation of proteins. Different bands were visualized by treating with staining solution (50\% methanol, $10 \%$ acetic acid and 1\% brilliant blue R250) for 30 minutes. Excess amount of dye was then distained by solution containing 50\% methanol and $10 \%$ acetic acid. Finally, photographs were captured using a cell phone camera. Since the effect of differences in shape and charge are eliminated by the SDS and $\beta$-mercaptoethanol treatment, the proteins in the gel separate into discrete bands according only to size. Small fragments are able to migrate faster through the gel than the larger ones. 


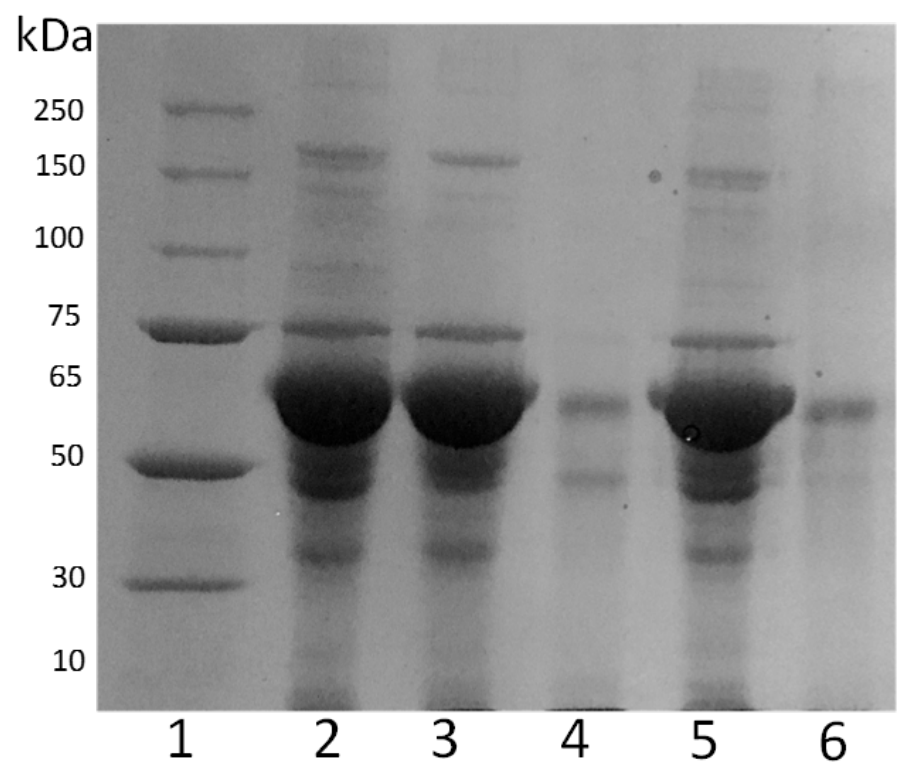

Figure S9. Isolation of antibodies from human serum analysed by SDS-PAGE electrophoresis. A $20 \mu \mathrm{L}$ undiluted human serum sample was treated with the commercial Protein A magnetic beads, $\mathrm{MB}_{\mathrm{A}}$ (lane 5) and with Protein A like nanopockets suspensions, $\mathrm{NP}_{\mathrm{A}}$ (lane 3 ) for comparison. Lane 4 and 6 represents the eluted antibodies from (4) $\mathrm{NP}_{\mathrm{A}}$ and (6) $\mathrm{MB}_{\mathrm{A}}$ respectively after treating with $0.2 \mathrm{M}$ glycine ( $\mathrm{pH} 2.5$ ). From each fraction, depleted serum proteins were separated by SDSPAGE and visualized by Coomassie brilliant blue staining. The others lanes are control lanes: (1) MW markers and (2) human serum.

Human serum consists of different antibodies with various molecular weight from $150 \mathrm{kDa}$ to $180 \mathrm{kDa}$. The treatment with SDS and $\beta$-mercaptoethanol produces fragments of antibodies. The heavy chain and the light chain should come in range of 50-60 kDa and 25-30 kDa range. The gel-electrophoresis data show the presence these bands (Figure S6, lane 4 and 6) in the eluted samples. These bands were slightly darker in lane 4 than lane 6 , suggesting that the $\mathrm{NP}_{\mathrm{A}}$ isolates antibodies than $\mathrm{MB}_{\mathrm{A}}$. However, this result is qualitative and sensitivity is not nearly good enough to make the clear conclusions reached from the LC-MS results in the main paper. 


\section{Statistics of adsorption isotherm}

Table S4. Reduced Chi-Squared and Reduced Sum of Square values generated for $\mathrm{NP}_{\mathrm{A}}$ and $\mathrm{MB}_{\mathrm{A}}$ in figure 3.

\begin{tabular}{|c|c|c|c|c|}
\hline \multirow{2}{*}{ Protein } & \multicolumn{2}{|c|}{ Reduced Chi-Squared } & \multicolumn{2}{c|}{ Residual Sum of Squared } \\
\cline { 2 - 5 } & $\mathbf{N P}_{\mathbf{A}}$ & $\mathbf{M B}_{\mathbf{A}}$ & $\mathbf{N P}_{\mathbf{A}}$ & $\mathbf{M B}_{\mathbf{A}}$ \\
\hline Mouse IgG & $\mathbf{2}$ & 0.0364 & 0.00574 \\
\hline Human IgG & 0.00561 & 0.00115 & 0.0364 & 0.01415 \\
\hline Human IgG & 0.00328 & 0.00283 & 0.01967 & 0.01658 \\
\hline Human IgA & 0.00377 & 0.00332 & 0.02261 & 0.01466 \\
\hline HSA & 0.00587 & 0.00293 & 0.03520 & 0.04647 \\
\hline PSA & 0.00324 & 0.00929 & 0.01946 & 0.01294 \\
\hline
\end{tabular}

\section{References}

(1) Mani, V.; Wasalathanthri, D. P.; Joshi, A. A.; Kumar C. V.; Rusling, J, F. Highly Efficient Binding of Paramagnetic Beads Bioconjugated with 100,000 or More Antibodies to Proteincoated Surfaces. Anal. Chem. 2012, 84, 10485-10491.

(2) Kumosinski, T. J.; Unruh, J. J. Global Secondary Structure Analysis of Proteins. In Kumosinski, T. J., Leibman, M. N. Molecular Modeling, ACS Symposium Series 576, Amer. Chem. Soc. Wash, D.C. 1994, pp. 71-99.

(3) Barth, A. IR Spectroscopy of Proteins, Biochimica Biophysica Acta 2007, 1767, 1073-1101.

(4) Kadimisetty, K.; Malla, S.; Bhalerao, K. S.; Mosa, I. M.; Bhakta, S.; Lee, N. H.; Rusling, J, F. Automated 3D-Printed Microfluidic Array for Rapid Nanomaterial-enhanced Detection of Multiple Proteins. Anal. Chem. 2018, 90, 7569-7577. 